\title{
Reflections about public use in conservation units such as subsidy to the promotion of nature conservation
}

\begin{abstract}
The public use can be defined how a use of conservation by visitors, that takes place from recreational activities, educational practices and tourism. That project had as objective show reflections about favoring the conservation of nature through public use in conservations unites, being a literature review. The found studies pointed that use public activities narrow the bond of the visities with the conservations unites, generating a belonging feeling, getting a bigger engagement with the conservation of nature. Concludes that the public use is a confederate of conservation of nature, reapproaching people with the natural environments.
\end{abstract}

Keywords: environment, conservation areas, public use

\author{
Volume 2 Issue 2 - 2018 \\ Mariana Meira Micaloski,' Caroline \\ Rodrigues Pereira, ${ }^{2}$ Ronaldo Viana Soares,' \\ Alexandre França Tetto' \\ 'Postgraduate Program in Forestry Engineering, Federal \\ University of Paraná, Brazil \\ ${ }^{2}$ Forestry Engineer, Federal University of Technology-Paraná, \\ Brazil
}

\begin{abstract}
Correspondence: Caroline Rodrigues Pereira, Forestry Engineer, Federal University of Technology-Paraná, R. Dep. Heitor Alencar Furtado, 5000-Campo Comprido, CuritibaPR-8I 280-340, Brazil, Tel +55(4I)996095326,

Email carolrodrigues.floresta@gmail.com
\end{abstract}

Received: October 01, 2017 | Published: April 12, 2018

\section{Introduction}

With the industrial revolution of the century XVIII the environmental problems began to be part of human daily life more intensely, in view of that this event triggered a humanity life standard for a productive and consumerist line. Therewith, from the century XIX emerged the fist concerns in relation to need for preservation and conservation of ecosystems, by means of the creations of protected areas, to ensure a quality life to now and future generations. In the world, the creation of Parque Nacional de Yellowstone, implanted in 1872 in The United States, was the historic mark in the creation iniciative of proteged national areas. In Brazil, this mark occurred with the creation of Parque Nacional de Itatiaia, in Rio de Janeiro, in $1937 .{ }^{1}$

The creations of national parks how proteged areas spread in a lot of countries and over time started to receive the denomination of Unidades de Conservação (UCs). However, the firsts UCs was established without technical or scientists criteria, being created by scenic beauty issues, resulting in inefficiency of creation and management, not having specific environmental objectives. ${ }^{2}$

Therefore, initially was established a conception of conservation based in landscape consumption in natural areas, ${ }^{3}$ being that with the wide dissemination in the creation of protected areas, the need for a systematization with technical and scientific basis.

This review had as objective introducing reflections about the favoring of nature conservation by means of public use activities in unities of conservation, like education, environmental interpretation and tourism. The methodological basement occurred through the bibliographic and documental apparatus about the subject, showing the success of the conservation unities, beyond of depending of a good planning and management, it depends too of the understanding and the participation of the population.

\section{Discussion}

The system of nature conservation unites (SNUC) of brazil and public use

"An analysis of priorities in conservation of nature in the Amazônia", published in 1976, was the document that guided the first versions of the plan of national conservation systems of Brazil. This document considered technical, scientific and political criteria in the indication of a system of after years of studies, proposals and procedures in the National Congress, Law No. 9,985 was instituted on July 18, 2000, which established the National System of Nature Conservation Units. ${ }^{1}$ This law establishes the criteria and norms for the creation and management of conservation unites and its article 2 defines UC as being, ${ }^{4}$ Territorial space and its environmental resources, including jurisdictional waters, with relevant natural characteristics, legally established by the Public Authorities, with conservation objectives and defined limits, under a special administrative regime, to which adequate protection guarantees are applied. ${ }^{4}$

According to the same author, the UCs that constitute the SNUC can be federal, state, municipal or private and are divided into two groups, those of integral protection and those of sustainable use.

The integral protection group has as basic objective the preservation of nature, allowing only the indirect use of natural resources, being constituted of the management categories: Ecological Station, Biological Reserve, National Park, Natural Monument and Wildlife Refuge. The conservation unites of sustainable use aim at the harmonization of nature conservation with the sustainable use of their resources, being composed of the following categories: Environmental Protection Area, Area of Relevant Ecological Interest, National Forest, Extractive Reserve, Wildlife Reserve, Sustainable Development and Private Reserve of Natural Heritage. 
According to the SNUC Law, conservation unites, in addition to the objectives of preservation and conservation of natural resources, according to its Article 4, item XII, also have the objective of "favoring conditions and promoting education and environmental interpretation, recreation in contact with nature and eco-tourism ". These activities characterize the public use that, according to the same law, can be carried out in some PAs, not being allowed only in the categories Ecological Station and Biological Reserve, of the integral protection group. ${ }^{4}$

According to Magro et al. ${ }^{5}$ public use in conservation unites can be defined as "usufruct enjoyed by the public", and can also be considered as the indirect use of natural resources, which occurs through different forms of visitation of a conservation unit. These uses can benefit protected areas, provided there is a good planning program that respects the vulnerabilities and potentialities of the area, so these activities must be managed by the management plan of the US. ${ }^{6}$

The public use programs concern the actions and activities required to attend the visitor, ordering, guiding and directing the uses of the conservation unit, aiming to offer activities to the community that raise a critical awareness of the importance of conservation of the environmental resources of the UCs. ${ }^{7}$

According to the "Guidelines for Visitation in Conservation Units" of the Ministry of the Environment, the activities of visitation should respect the objectives proposed for the UC and provide the approximation of society with nature, raising awareness of the importance of conservation of natural environments. ${ }^{8}$

\section{Environmental education}

Environmental Education (EA) gained significance in 1977, when it was recognized internationally at the Intergovernmental Conference on Environmental Education in Tbilisi, Georgia, when the goals, objectives, principles and strategies for the encouragement of EA were established. ${ }^{9}$

In Brazil, EA was regulated by Law No. 9,795 of April 27, 1999, which provides forenvironmentaleducation andestablishes the National Environmental Education Policy, which, in its article 1, defines EA as: The processes through which the individual and the community construct social values, knowledge, skills, attitudes and skills aimed at the conservation of the environment, A common good of the people, essential to the healthy quality of life and its sustainability. ${ }^{10}$

According to the same law, EA must be worked at all levels and modalities of the educational process, both formal and non-formal. Environmental education in formal education must be developed as an "integrated, continuous and permanent educational practice at all levels and modalities of formal education", and it must be worked in a transversal and interdisciplinary way. Non-formal EA is understood as "educational actions and practices aimed at raising public awareness about environmental issues", being disseminated through the media and development of programs with the participation of public and private companies, schools, universities and organizations nongovernmental organizations..$^{10}$

Carvalho et al. ${ }^{11}$ ponders environmental education as a concern of ecological movements with the practice of raising society's awareness of environmental problems. Cerrati et al. ${ }^{12}$ believe that environmental education, through sensitization and the awakening of a critical conscience, becomes one of the main strategies for the conservation of nature, stimulating the participation of the population in the protection of natural resources.

There are several problems that surround the management and maintenance of conservation unites and environmental problems are not the only ones found in the areas, there are also economic, social and political conflicts. ${ }^{13}$ Most of the problems faced by UCs are related to anthropogenic pressures, and it is possible to emphasize the removal or permanence of populations in these areas and conflicts with the surrounding inhabitants. ${ }^{14}$ Padua et al. ${ }^{15}$ describes that, generally, the surrounding populations are seen as sources of negative impact on conservation unites, however, they can become allied to the conservation of these areas if inserted properly through environmental education. For Moran et al. ${ }^{16}$ education, in addition to teaching, must integrate education with life, reflection with action, enabling a vision of totality. Thus, environmental education has importance in the development of the understanding of the relationship between man and nature. ${ }^{17}$

\section{Environmental interpretation}

Environmental Interpretation (EA) is ways of making people understand the environment and its ecological environment, translating the language of nature into the common language of people. ${ }^{18}$

Tilden et al. ${ }^{19}$ conceptualizes the interpretation as being an educational activity that works the existing relationships in the environment through the use of objects and experiments going beyond simple literal informal communication. Being is an educational activity that seeks learning through doing, asking, reflecting and responding. ${ }^{18}$

Environmental interpretation is a participatory way of explaining the concepts of the natural and cultural environment through the use of the five senses, which should be transmitted in a playful way, allowing an easier absorption by the visitors. ${ }^{20}$

Environmental interpretation contributes to optimize the visitor's experience in the conservation unit, helping not only the scientific understanding of the protected area, but also about the nature conservation in the world, and can influence their attitudes and values. ${ }^{20}$

Like environmental education, environmental interpretation is an efficient instrument for the rapprochement of people with the environment, which stimulates reflections on the relationship between man and nature. ${ }^{18}$

\section{Eco tourism}

Tourism, in addition to considering the economic factor, began to consider the environmental problems in its activities. This change occurred mainly in the 1980 s, when this segment began to highlight the need for revaluation of the environment, ${ }^{21}$ appearing tourism in contact with nature.

The Ministry of Tourism ${ }^{22}$ defines tourism in contact with nature, also known as ecotourism, as the "tourism activity that uses, in a sustainable way, natural and cultural heritage", also possessing principles which aim to promote the environmental awareness of its practitioners. Ecotourism is not only based on the idea of "walking" through natural areas, it is also characterized in activities that provide the experience and knowledge of the nature and protection of these environments, thus establishing itself on the tripod of interpretation, 
conservation and sustainability. For Lindberg et al..$^{23}$ ecotourism must provoke and satisfy the desire to be in contact with nature, exploring the tourist potential for the conservation of the environment and avoiding negative impacts on the ecology, culture and aesthetics of the area.

Ecotourism is not only based on tourist behavior, it also takes into account the construction of spaces for public use and its organization, reconciling conservation, preservation, management and recovery with other activities. It is also necessary to encourage the environmental interpretation through information about the natural environment and its culture, as well as the promotion of environmental education, aiming to awaken a sustainable awareness in visitors. ${ }^{22}$

\section{Conclusion}

With the reflections put forward in this work it is possible to affirm that public use is an ally of nature conservation, because its activities allow people to reapproximate with natural environments, allowing visitors to reflect on how their actions affect the environment and conservation unites. Gonh et al. ${ }^{24}$ states that the importance of public uses in the conservation of protected areas is due to the sensitization that the "taking part" arouses in the visitors, generating a sense of belonging to the area, narrowing their affective bond with the place and generating a greater commitment to nature conservation projects.

\section{Acknowledgements}

The authors Mariana Meira Micaloski and Caroline Rodrigues Pereira made the bibliographical review of this article. Ronaldo Viana Soares and Alexandre França Tetto made the orientation for the assembly of the article, besides the organization of ideas.

\section{Conflict of inertest}

Authors declare there is no conflict of interest.

\section{References}

1. Schenini PC, Costa AM, Casarin VW. Unidades de conservação: aspecto históricos e sua evolução. Trabalho apresentado no 6. Brasil: Congresso Brasileiro de Cadastro Técnico Multifinalitário; 2004. p. 1-7.

2. Pádua MTJ. Categorias de unidades de conservação-objetivos de manejo. Brasil: Boletim FBCN; 1978.

3. West P, Igoe J, Brockington D. Parks and people: the social impact of protected areas. Annual Review of Anthropology. 2006;35:251-277.

4. Brasil. Lei $n^{0}$ 9.985, de 18 de julho de 2000. Brasil: Institui o Sistema Nacional de Unidades de Conservação da Natureza e dá outras providências, Disponível; 2017.

5. Magro TC. Impactos do uso público em uma trilha no planalto do Parque Nacional de Itatiaia.135 f. Tese (Doutorado em Engenharia Florestal)Escola de Engenharia de São Carlos, Brasil: Universidade de São Paulo; 1999.

6. Silva AOD, Castro AOCD. Avaliação dos impactos de uso público na trilha ecológica da Praia do Perigo-Parque Estadual de Grumari, RJ. In Encontro fluminense de uso público em unidades de conservação. Brasil: Universidade Federal Fluminense. 2015. p. 293-304.
7. Ministério do Meio Ambiente-MMA. Marco conceitual das unidades de conservação federais do Brasil. Brasil: Diretoria de Ecossistemas e Vida Silvestre; 1997. p. 1-26.

8. Ministério do Meio Ambiente-MMA. Diretrizes para visitação em unidades de conservação. Brasil: Ministério do Meio Ambiente; 2006. p. $1-65$.

9. Ministério do Meio Ambiente-MMA. Educação ambiental: por um Brasil sustentável. Brasil: Ministério do Meio Ambiente; 2014. p. 1-114.

10. Brasil. Lei ${ }^{\circ} 9.795$, de 27 de abril de 1999. Dispõe sobre a educação ambiental. Brasil: Instituia Política Nacional de Educação Ambiental e dá outras providências. Disponível; 2017.

11. Carvalho ICDM. Educação ambiental: a formação do sujeito ecológico. 2nd edition. Brasil: Cortez; 2006. 256 p.

12. Cerati TM, Lazarini RADM. A pesquisa-ação em educação ambiental: uma experiência no entorno de uma unidade de conservação urbana. Ciência \& Educação. 2009;15(2):383-392.

13. Brito DMC. Conflitos em unidades de conservação. Brasil: Revista de Humanidades do Curso de Ciências Sociais UNIFAP; 2008. p. 1-12.

14. Arruda R. "Populações tradicionais" e a proteção dos recursos naturais em unidades de conservação. Ambiente \& Sociedade. 1999;2(5):79-92.

15. Pádua SM. Educação ambiental em unidades de conservação. In: Gestão de unidades de conservação: compartilhando uma experiência de capacitação. Brasil: WWF; 2012. p. 1-397.

16. Moran JM. Ensino e aprendizagem inovadores com tecnologias audiovisuais e telemáticas. Informática na Educação: teoria \& prática. 2000;3(1):137-144.

17. Dias GF. Educação ambiental: princípios e práticas. 8th edition. Brasil: Gaia; 2003.

18. Vasconcellos JMDO. Educação e interpretação ambiental em unidades de conservação. Brasil: Fundação O Boticário de Proteção à Natureza; 2006.

19. Tilden F. Selecciones de 'interpretando nuestra herencia'. USA: CATIE; 1977.

20. Nelson SP. Uso público nas unidades de conservação. In: Gestão de unidades de conservação: compartilhando uma experiência de capacitação. Brasil: WWF; 2012. p. 217-238.

21. Fontoura LM, Silveira MATD. Turismo em unidades de conservação e planejamento territorial: um foco no Parque Estadual de Vila Velha-PR. In: Seminário de pesquisa em turismo do mercosul, Brasil: University of Caxias do Sul; 2008.

22. Ministério do Turismo-Mtur. Ecoturismo: orientações básicas. 2nd edition. Brasil; 2010. p. 1-96.

23. Lindberg K, Hawkins D. Ecoturismo: um guia para planejamento e gestão. 4th edition. Brasil: Senac; 2002.

24. Gohn MDGM. Conselhos gestores e participação sociopolítica. Brasil: Cortez; 2011. 